\title{
US DIVIDEND POLICY ANALYSES
}

\author{
Michael Wijaya \\ Accounting and Finance Department, Faculty of Economics and Communication, BINUS University \\ Jln. K. H. Syahdan No. 9, Palmerah, Jakarta Barat 11480 \\ mhadipoespito@binus.edu
}

\begin{abstract}
The main issue writer examines in this writing is to analyze whether or not dividend policy is a determinant to maintain stock values or firm values as a whole. It is essential that dividend policy is managed properly to enhance the satisfaction of the investors at any level of characteristics. At the end, investors are the key that determines the stock value movement. Some investors are looking for capital gain and some do care about dividend payout. Thus, the decision of dividend policy becomes crucial. It needs to understand that a firm's dividend policy may have effects on shareholder welfare. The answers can be found out by analyzing different factors of dividend policy. Taken as a whole, to see if there are other alternatives if dividend policy that can maintain or even boost up firm values. Different dividend policy has some upsides and downsides that a corporation needs to consider. One of the alternatives that is common and has become a key is stock repurchase plan.
\end{abstract}

Keywords: dividend policy, factors of dividend policy, stock values, investor satisfaction, shareholder welfare

\begin{abstract}
ABSTRAK
Pokok permasalahan yang dibahas pada tulisan ini adalah untuk menganalisis apakah aturan dividen menjadi faktor penting untuk mencinptakan nilai saham atau nilai perusahaan yang kuat. Mengatur aturan dividen dengan baik sangat penting untuk meningkatkan nilai kepuasan pemilik saham yang berbeda-beda karakter. Perlu diingat bahwa pemilik saham memiliki peranan yang kuat dalam menentukan pergerakan nilai saham; dan beberapa pemilik saham peduli dengan dikeluarkannya dividen yang rutin. Ada juga yang lebih peduli dengan kenaikan harga saham. Oleh karena itu, keputusan dalam pengeluaran dividen mempunyai peranan penting. Perlu dipahami bahwa aturan dividen akan mempunyai efek di tingkat kepuasan pemilik saham. Jawabannya bisa diketahui dengan menganalisis beberapa faktor aturan dividen dan juga dengan melihat jika ada alternatif untuk mempertahankan atau meningkatkan nilai perusahaan. Beberapa aturan dividen memiliki akibat positif dan negatif yang perlu diperhatikan perusahaan. Salah satu alternatif penting yang sudah banyak dipakai adalah membeli kembali saham yang sudah beredar di publik oleh perusahaan.
\end{abstract}

Kata kunci: aturan dividen, faktor aturan dividen, nilai saham, kepuasan investor, kesejahteraan pemegang saham 


\section{INTRODUCTION}

Questions about whether firms should pay dividends and whether a firm's dividend policy affects shareholder welfare have been at an interesting and unresolved controversy among financial economists. While dividends are not that complex, the reasons behind dividend issuance may vary and some insights can be inferred in term of its role. There are three different explanations that can be examined. (1) Dividends are irrelevant. That is, investors only care about total returns. Since dividends and capital gains are perfect substitutes, investors do not care how the total return is allocated between them. (2) Dividends are effectively taxed at higher rates then capital gains, and, therefore, cannot be viewed as perfect substitutes. This suggests that dividend paying firms should have lower stock prices. (3) Dividends may provide investors with information about a firm's future earnings power. For example, large dividend cuts are considered bad news and cause stock prices to drop.

\section{Literature Review}

\section{The Dividend Irrelevance Issue}

The main question that needs to be addressed in this section is whether managers are able to affect shareholder welfare through dividend policy. The explanation below will show that, in a world without taxes, firm value is not affected by dividend policy. The intuition can be described in the following manner. Suppose management has an investment decision to make. Will the investment decision affect the amount of dividends a firm pays? Or, will dividend policy determine how much capital is available for new investment? If managers view dividends as a binding commitment that constrains them from taking all positive NPV projects the answer is yes. By contrast, if managers are willing to raise new capital (debt or equity) to fund good projects, the answer is no. As long as investment and dividend decisions are independent, dividend policy is irrelevant. The best way to illustrate this point may be through a simple numerical and theoretical example.

A Numberical Example. Consider a firm with the following riskless cash flows (see Table 1).

Table 1 a Firm with Riskless Cash Flows

\begin{tabular}{|l|r|r|r|}
\hline \multirow{2}{*}{} & \multicolumn{3}{|c|}{ Time } \\
\cline { 2 - 4 } & 1 & 2 & 3 \\
\hline Cash Flows & 100 & 100 & 265.5 \\
\hline
\end{tabular}

Suppose that cash flows are paid to shareholders as they are earned. If the risk free rate is $10 \%$, the stock has a current market price of $\$ 373.03$. That is,

$$
\mathrm{P}_{0}=\sum \frac{\mathrm{CF}_{\mathrm{t}}}{(1+\mathrm{R})^{\mathrm{t}}}=\frac{100}{1.1^{1}}+\frac{100}{1.1^{2}}+\frac{100}{1.1^{3}}=373.03
$$

Table 2 describes two alternative dividend payout policies. Which one would you prefer? 
Table 2 Two Alternative Dividend Payout Policies

\begin{tabular}{|l|r|r|r|}
\hline & \multicolumn{3}{|c|}{ Time } \\
\cline { 2 - 4 } & 1 & 2 & 3 \\
\hline Policy 1 & 150 & 150 & 150 \\
\hline Policy 2 & 50 & 50 & 381 \\
\hline
\end{tabular}

The present value of the equity under policies 1 and 2 are:

Policy 1:

$$
\mathrm{P}_{0}=\sum \frac{\mathrm{D}_{\mathrm{t}}}{(1+\mathrm{R})^{\mathrm{t}}}=\frac{150}{1.1^{1}}+\frac{150}{1.1^{2}}+\frac{150}{1.1^{3}}=373.03
$$

and

Policy 2:

$$
\mathrm{P}_{0}=\sum \frac{\mathrm{D}_{\mathrm{t}}}{(1+\mathrm{R})^{\mathrm{t}}}=\frac{50}{1.1^{1}}+\frac{50}{1.1^{2}}+\frac{381.5}{1.1^{3}}=373.03
$$

Notice that share price is the same under either policy. The next step shows that these policies are feasible. Policy 1 requires the firm to borrow money to make a relatively high early dividend payment.

Table 3 Policy 1

\begin{tabular}{|r|r|r|r|}
\hline & \multicolumn{3}{|c|}{ Time } \\
\cline { 2 - 4 } & 1 & 2 & 3 \\
\hline Cash Flow & 100.00 & 100.00 & 265.50 \\
Dividend & 150.00 & 150.00 & 150.00 \\
\cline { 2 - 4 } & $(50.00)$ & $(50.00)$ & 115.50 \\
Borrowing & 50.00 & $(55.00)$ & - \\
Borrowing & - & 105.00 & $(115.50)$ \\
\cline { 2 - 4 } & 0 & 0 & 0 \\
\hline
\end{tabular}

In order to make a relatively high dividend payment in year 3, Policy 2 requires that the firm invest excess cash flows.

Table 4 Policy 2

\begin{tabular}{|r|r|r|r|}
\hline & \multicolumn{3}{|c|}{ Time } \\
\cline { 2 - 4 } & 1 & 2 & 3 \\
\hline Cash Flow & 100.00 & 100.00 & 265.50 \\
Dividend & 50.00 & 50.00 & 381.00 \\
\cline { 2 - 4 } & 50.00 & 50.00 & $(115.50)$ \\
Investment & $(50.00)$ & 55.00 & - \\
Investment & - & $(105.00)$ & 115.50 \\
\cline { 2 - 4 } & 0 & 0 & 0 \\
\hline
\end{tabular}

A Theoritical Example. The following is to demonstrate the irrelevance result in a more general setting. Suppose the optimal investment decision is $I^{*}(1)$ and the payoff from the prior period's investment is $\mathrm{NOI}(1)$ (assume that $\mathrm{NOI}(1)>\mathrm{I}^{*}(1)$ ). If the firm pays a dividend, $\mathrm{D}(1)$, such that 


$$
\mathrm{D}(1)<=\mathrm{NOI}(1)-\mathrm{I}^{*}(1),
$$

the firm can make the optimal investment decision using internally generated funds. If $\mathrm{D}(1)>\mathrm{NOI}(1)$ $-I^{*}(1)$, what are the firm's alternatives?

Alternative 1, it could make a suboptimal investment decision I(1) such that

$$
\mathrm{I}(1)=\mathrm{NOI}(1)-\mathrm{D}(1)
$$

This implies that $\mathrm{I}(1)<\mathrm{I}^{*}(1)$. This is clearly undesirable since presumably the firm must pass up positive NPV projects in order to make the dividend payment.

Alternative 2, it could borrow the difference in the capital markets by issuing stock, bonds or some combination thereof. That is,

$$
\mathrm{NOI}(1)+\mathrm{E}(1)+\mathrm{B}(1)=\mathrm{I}^{*}(1)+\mathrm{D}(1)
$$

In this scenario, the firm paid the existing shareholders a dividend and used the capital markets to fund the short fall. $\mathrm{E}(1)$ and $\mathrm{D}(1)$ denote the amount of equity and debt financing, respectively. Modigliani and Miller argue that, since the firm has made the optimal investment decision, firm value is unaffected by the dividend decision and, consequently, dividend policy is irrelevant. That is, the way equity cash flows are split between original and new shareholders doesn't affect firm value provided the new shares are issued at a fair price.

\section{RESULTS AND DISCUSSION}

\section{The Tax Effect Issue}

The most obvious place to begin relaxing the Modigliani and Miller assumption is taxes. In the US, dividend payments by a corporation are not tax deductible for corporate tax purposes. The same is not true for individual tax payers. Historically, dividends have been taxed at higher rates than capital gains at the personal level. The tax code changes over time and currently, dividends are taxed at the same rate as long-term capital gains. The code still favors long-term capital gains but only to the extent that investors can defer recognition until the security is sold. Thus, superficially, the US tax code appears to favor a low dividend payout policy. Next is a closer look at how investment income is taxed at the individual level.

Dividend Taxation. Dividends paid by domestic corporations (qualified dividends) are taxed at a maximum rate of $15 \%$. All other dividends are taxed at ordinary rates. Firms sometimes pay special dividends. These dividends typically include a return of capital. The portion that reflects capital is non-taxable. A liquidating dividend is an example of a special dividend.

Capital Gains Taxation. The rules that govern capital gains are complicated. The primary implications are that short-term capital gains are taxed at ordinary rates, and long-term capital gains are taxed at a maximum rate of $15 \%$. Notice that this is the same rate that applies to qualified dividends. A security must be held for at least one year to qualify for long-term capital gains. There is a complicate set of rules that nets long- and short-term capital gains and losses. If there is a net capital loss, investors may offset this amount against ordinary income up to a maximum of $\$ 3,000$.

Financial economists have investigated a number of possible ways to determine if dividend policy affects stock prices. The following approaches can be considered: price drops on ex-dividend days and cross-sectional analysis of stock returns and dividend yields. 
If an investor buys a stock before the ex-dividend day, she is entitled to receive the dividend. If she buys it on the ex-dividend day, she is no longer entitled to the dividend. This leads to the prediction that stock prices will drop by the after-tax value of the dividend. If the marginal investor has a $23 \%$ tax rate, a $\$ 1$ dividend will cause the stock price to drop by $\$ 0.77$ on the ex-dividend date.

Surprisingly, Elton and Gruber found that, on average, stock prices dropped by $\$ 0.77$ on the dollar. They also found that stocks with dividend yields exceeding $5 \%$ experienced price declines of $\$ 0.90$. For the smallest dividend yields, the price drop was close to $50 \%$. Taken together, this supports the investor clientele hypothesis. That is, firms that pay large dividends attract investors in relatively low tax brackets, and firms that pay small dividends attract investors in the highest tax brackets.

Unfortunately, other explanations for this result are equally if not more plausible. Kalay (1982) argues that the Elton and Gruber findings are consistent with a popular tax arbitrage strategy. To see how it works consider a stock that is currently selling for $\$ 20$ and is about to pay a $\$ 1$ dividend. Traders can buy the stock for $\$ 20$, receive a dividend of $\$ 1.00$ and sell the stock the next day for $\$ 19.23$. Because the capital loss from this price drop is fully taxable at the personal income tax rate for short-term traders, this transaction results in an after tax gain

Non-taxable institutions use "dividend capture" strategies to exploit tax arbitrage opportunities. For example, non-taxable Japanese mutual funds exploited these opportunities to such a degree that the price drop was effectively $\$ 1$, reflecting a marginal tax rate of zero. Japanese mutual funds did this for two reasons: tax arbitrage and dividend distributions. There are regulations in Japan that restrict funds from distributing the principal. They are allowed to distribute dividends. A dividend capture strategy allows these funds to collect dividends, which can then be distributed to investors.

\section{The Information Content Issue}

Management often has significant inside information about a firm's prospects that it cannot (or chooses not to) divulge to investors; and the mere possibility of this information gap between management and shareholders causes stock prices to be lower than they would be if everyone shared the same information. Corporate dividends may be management's most cost effective means of overcoming the investor uncertainty resulting from this potential informational asymmetry. By periodically and predictably raising the dividend, management effectively binds itself to make a series of future payments to stockholders; and this commitment, which is costly in terms of management's future flexibility (it is a common understanding how reluctant managers are to cut dividends), provides investors with the assurance that management is not sitting on some important piece of negative information.

This creates a problem for managers who need to raise funds to finance the optimal investment decision. Potential stockholders realize that management has an incentive to issue stock when the market currently overvalues it, and defer issuing stock when it is currently undervalued. As a result, they will discount what they are willing to pay for the stock so that on average they expect to breakeven. This inefficiency implies that management will be unable to raise as much capital as the optimal investment policy would indicate.

As a result, the firm's investment decisions and dividend policy are no longer independent. Thus, dividend policy can affect firm value. Once this possibility is introduced, it may be possible to find a dividend decision that maximizes firm value.

It has been difficult to establish a direct link between changes in dividend policy and stock prices. The reason may be that dividends are discretionary and small changes in dividends do not convey much information. The most interesting studies in this area examine market reactions to 
extreme changes in dividend policy. Healy and Palepu (1988) find that dividend initiators and firms paying dividends for the first time in ten years experience positive abnormal returns of $3.9 \%$. Firms that omit dividends for the first time in ten years experience negative abnormal returns of $9.5 \%$. Dielman and Oppenheimer (1984) examined a sample of firms that cut dividends by more than $25 \%$ and firms that omitted dividends and found abnormal returns of $-7.7 \%$ and $-8.1 \%$ on the announcement date.

One of the interesting aspects of the Healy and Palepu study is that they examine the relation between dividend changes and future earnings. They find that dividend initiators experience increases in earnings in the year prior to, the year of, and two years following a dividend increase. For firms that omit dividends, earnings are down in the year prior to the omission but they appear to recover in subsequent years. They also find that abnormal stock price reactions are positively correlated with earnings changes in the year following the dividend policy change. This suggests that dividend changes convey information about future earnings prospects.

These findings suggest that, on average, investors respond to the dividend announcements as if increases are good news and decreases are bad news. That is, dividend increases appear to signal that firms expect to have high cash flows, and should have higher stock prices. Unfortunately, these reactions to dividend policy changes may create perverse investment incentives that affect intrinsic value. By cutting investments in items that cannot be regularly seen by security analysts, firms can increase reported earnings and dividends, thereby increasing their stock prices. A manager's incentive to temporarily boost stock prices may lead him to pass on positive NPV projects.

Another problem is that investors are often unable to infer the quality of a firm's investment opportunities. Thus, unanticipated changes in dividend policy can send mixed signals. If dividends are increased, it could be a signal that managers have run out of profitable ideas and are going to begin a gradual liquidation of the company. Alternatively, it may indicate that past investment decisions have proven to be profitable and that managers wish to credibly convey this message by promising to pay higher dividends. A decrease in dividends may suggest that managers need to retain capital to further develop investment opportunities. Alternatively, it may signal that earnings will be lower in the future and that manager's cannot commit to pay relatively high dividends.

The study by Lang and Litzenberger looks at this issue in an indirect fashion. They find that firms with high growth opportunities (as a proxy by the market-to-book ratio) have economically small stock price reactions to dividend announcements. By contrast, stock price reactions are much larger for firms with relatively poor investment opportunities. Firms with relatively poor investment opportunities that cut dividends experience a negative abnormal return of $-2.7 \%$, while those that increase dividends have a significantly positive stock reaction of $0.8 \%$. This suggests that, for firms with relatively poor investment opportunities, investors like it when managers give up managerial discretion and punish firms that permit their managers to increase the amount of managerial discretion.

\section{Dividend Policy: Alternative Distribution Mechanisms}

The bottom line is that shareholders purchase stock to receive a share of a firm's earnings. The typical approach is to distribute these earnings as cash dividends. In the perfect market world we considered earlier, investors are indifferent to receiving dividends now or later provided the firm does not invest excess cash in assets that dissipate wealth. Once we move away from this unrealistic setting, dividends do matter. Investors infer future earnings prospects from changes in payout levels. Different tax treatments for dividends relative capital gains also affect stock prices.

One way for a corporation is to have stock repurchase plans as an alternative mechanism for distributing cash to shareholders. Share repurchase plans can have significant tax advantages. For the same payment level, dividends incur high tax liabilities because they are taxed at ordinary income 
rates, which can be as high as $39.6 \%$. By contrast, stock repurchase plans qualify for capital gains treatment. As a consequence, shareholders only pay taxes based on their capital gain rather than the entire payment. The portion that constitutes the investors tax basis is not taxable. Also, the maximum tax rate on the capital gain only is $28 \%$.

Another advantage of stock buybacks relative to dividends is that they tend to send stronger signals to the market. In general, dividends appear to be perceived by the stock market as regularly scheduled news releases conveying management's on-going assessment of a company's prospects. A stock buyback, on the other hand, is viewed as an "extra" news bulletin that is justified when managers feel that the stock is significantly undervalued. A stock buyback also may send a stronger signal to the market because it is often financed with costly external funds; in essence, management is "putting its money where its mouth is" with a buyback. Dividends, on the other hand, are rarely financed with external funds.

The recent popularity of this form of distributing cash makes it worthy of examining. Total stock repurchase increased from $\$ 3.5$ billion in 1978 to over $\$ 36$ billion in 1993 . The following companies announced potential stock buybacks of $\$ 1$ billion or greater in size during 1994: AnheuserBusch, McDonald's Corp., Merck, 3M, PepsiCo, Philip Morris, and Toys “R' US.

\section{Potential Benefits}

Convey Positive Information to Investors. Repurchase programs can be used to signal management's belief that the stock is undervalued. Since management is typically in a better position to understand the company's future prospects, investors are inclined to respond favorably to the announcement of a buyback program. Studies have demonstrated excess returns of $2 \%$ to $3 \%$ around the announcement of open-market stock repurchases with an excess return of $13 \%$ over the four years following the announcement. Stock price increases of $13 \%$ to $17 \%$ are associated with exchange offers, while increases of $11 \%$ to $14 \%$ are associated with tender offers.

Enhance Value of Investment. The idea that the firm's stock is a good investment relates to the market's undervaluation. Since it is tempting to invest excess cash by diversifying away from the core business, it puts this cash in the hands of shareholders and allows them to diversify on their own. Such an action may have the undesired affect of signaling to investors that the firm has run out of profitable investment ideas.

Move Toward an Optimal Capital Structure. A stock repurchase plan increases leverage. If the plan is financed by external borrowing, as are most plans, the impact on leverage is even greater. This is a simple way to move the firm closer to it is an optimal capital structure if it is under-levered.

Increase Return on Equity and Earnings Per Share. A repurchase program often increases a company's return on equity (ROE) and earnings per share by decreasing the number of shares outstanding.

Acquire Shares for Stock Option, Dividend Reinvestment and Employee Stock Ownership Plans. A repurchase program can be used to accumulate the shares necessary to satisfy various stock option, dividend reinvestment, and employee stock option programs.

Enhance Management Incentives. A significant share repurchase may increase a company's proportionate ownership by management and employees. This can align management and employee incentives more closely with those of shareholders.

Investor Tax Options. When shareholders tender shares they pay capital gains taxes. While this is tax advantaged relative to ordinary dividends, some shareholders may prefer to avoid any tax 
payments in the current period. Repurchase programs give shareholders the option to take cash now or later (by selling shares).

\section{Potential Costs}

Convey Negative Information to Investors. A share repurchase program may communicate that management has run out of profitable investments. This implies that the manner that the program is communicated to the investing public may have a significant impact on the way it is perceived.

Dilute Cash Reserves and Deplete Debt Capacity. Since repurchase programs use excess cash and increase leverage, it may impair the firm's ability to raise new capital at attractive rates. A firm could find its credit rating lowered.

Decrease Stock's Liquidity. Since repurchase programs remove stock, it reduces the number of potential traders, thereby potentially reducing liquidity.

\section{CONCLUSION}

So after all analyses, in summary, dividend is not a simple issue in the US market. It is a simple process of issuance and decision-making, but it a complex consideration of how many to issue and why a corporation needs to issue.,Dividend policy encompasses three main factors to consider such as distributing or investing the excess cash flow, tax issues, and information signaling strategy. All these factors play a big role in the perception creation of the corporation. However, there is an alternative of dividend distribution mechanism through share repurchase plan. Though this way is rather tad costly, but with a proper planning, share repurchase plan's benefits outweighs the drawbacks. A proper planning of share repurchase plan can be another huge issue of discussion. At the end, investors purchase stock to receive a share of a firm's earnings, which is normally distributed through dividends; however, investors may have different perspective of investing and earning purposes which could be through an expectation of capital gain. As a result, to maintain a strong fundamental of enterprise value, dividend policy becomes a critical function that needs to be managed accordingly.

\section{REFERENCES}

Baker, H. K. (2009). Dividends and Dividend Policy. Kolb Series in Finance.

Dielman, T. E., and Oppenheimer, H. R. (1984). The Information Content of Large Dividend Changes. Financial Review.

Healy, P. M., and Palepu, K. G. (2001). Information Asymmetry, Corporate Disclosure and the Capital Markets: A Review of the Empirical Disclosure Literature. Journal of Accounting and Economics.

Kalay, A. (1982). The Ex-Dividend Day Behavior of Stock Prices: A Re-Examination of the Clientele Effect. The Journal of Finance.

Miller, M. H. (1988). The Modigliani-Miller Proposition after Thirty Years. The Journal of Economic Perspectives. 